\title{
Corporate Social Responsibility Based on Essential Awareness
}

\author{
La Ode Sumail and Rahman Pura \\ Sekolah Tinggi Ilmu Ekonomi Makassar (STIEM Bongaya) Indonesia \\ email:odesumail@yahoo.co.id and sahman_aslam@yahoo.com
}

\begin{abstract}
This study tries to investigate the relevance of the implementation of CSR based on the values of awareness related to governance, financial performance, and ihsan spirit. The manager of Islamic banks as respondents. They are given the freedom to determine opinions or opinions according to what they experience with a range of assessments 1-5. In order to get accurate information, trials, validity tests, reliability tests, data editing, data tabulation, linearity assumption tests, and data analysis through generalized structured component analysis (GSCA). Governance characterized by sharia concepts encourages awareness-based CSR implementation. If good governance, good financial performance, and strong spirituality, then awareness of implementing CSR is getting higher. Photographs of awareness of implementing CSR are not limited to accommodating the interests and needs of stakeholders as sounded by stakeholder theory and not merely explaining the behavior of boundaries and norms of society such as pulses theory, but behind the awareness of giving there is the power of giving that is a new spirit and the company is on the hill of victory. Indicators used are based on sharia concepts. CSR has intrinsic awareness not found in conventional companies and banks.
\end{abstract}

Keywords: corporate goog governance, performance, ihsan spirit, CSR.

\section{INTRODUCTION}

There is a stigma that corporate social responsibility (CSR) is the answer to the social uncertainty of the company's business activities (Beurden, 2008). However, behind the answers to uncertainty, there are hidden motives for implementing CSR, especially for companies in Indonesia. The implementation of CSR in Indonesia can be interpreted as limited to the strategy of breaking sins for the mistakes and greed that the company had previously done and is still limited to reducing complaints or resistance from the public and the government and seemingly cosmetic.

Some theories related to CSR disclosure such as stakeholder theory and legitimacy theory. The view of stakeholder theory was initiated by (Freeman, 1984) that CSR activities are carried out to accommodate the wants and needs of stakeholders. So that companies can move well (Luoma-aho et al., 2010; Maharaj, 2008; Money et al., 2012). The strength of this theory is able to bridge ethics and capitalism. In addition, it is able to combine social contracts and company decisions so as to increase the value of the company (Beckman et al., 2016). While the legitimacy theory is only able to explain that the company operates in a changing external environment. Therefore, they try to make sure that their behavior is in accordance with the boundaries and norms of society. In addition, legitimacy theory focuses on interactions between companies and society (Lanis and Richardson, 2013; Luke et al., 2013; Mohamed et al., 2014).

It can be mentioned that the stakeholder theory and legitimacy theory have inspired many researchers to review the phenomenon of CSR implementation. However, there has 
not been a comparison of the values of giving awareness. CSR must also be interpreted as a movement or a culture of giving and not being pretended to be fake. Indeed, running CSR must be framed with a sacred mission, love, sincere, spontaneous, expressed with joy, and not experiencing fatigue. It is believed, the movement or culture of giving becomes an adhesive and can reduce complaint tension between companies and stakeholders and can meet the demands of government regulations.

Many studies on CSR have been focused on the aspects of obligation to reduce complaints or community resistance as well as the demands of government regulations (Kriyantono, 2015) and volunteering. CSR should not be forced because it is voluntary and becomes part of the company's strategy (Andrews, 2016; Myburgh, 2001). Therefore, the face of CSR implementation is still cosmetic. In fact, the implementation of CSR becomes an essential awareness of the company.

Seeing the fact that it increasingly attracts the issue of intrinsic awareness for CSR management researchers, particularly those who are observers of financial management. This study tries and proposes a new concept that implementing CSR must be seen as essential awareness. That is, disclosure of CSR places religion as the basis for explaining why organizations disclose social information and also in evaluating organizational performance in terms of fulfilling their obligations to God, society and ecosystems. The reason, companies are beginning to realize that behind the sacrifice of the company's economic resources has drained profits and dividends for shareholders, companies can reap multiplier benefits if they care about CSR. These benefits, such as increased reputation, increased consumer loyalty (Afifah and Asnan, 2015; Ramli et al., 2015; Ramli et al., 2014), increased performance and decreased community resistance (Chen et al., 2008).

This is what underlies the conduct of this study and it is believed that a complete explanation can be obtained. It can be believed that the faces of companies that have implemented CSR with the concept of intrinsic awareness tend to be different compared to the faces of companies that are not based on intrinsic awareness like companies that rely on conventional concepts. Corporate behavior with intrinsic awareness tends not to show the cultural face of cultural values and religious values. Corporate governance models tend to have strong business ethics and can strengthen the implementation of CSR. Therefore, CSR can be placed as a cultural and religious power of essential awareness (Mooij and Hofstede, 2007; Pierre and Florence, 2016).

There has been a lot of strong evidence about the relationship between corporate governance and CSR, as previous researchers such as (Esa et al., 2012; Sun et al., 2010) state that the better corporate governance is the better implementation of CSR. However, the evidence they reveal has not found a comparative religious value in managing the company and disclosure of CSR. In fact, if governance is packed with a shield of Islamic values the company will be able to grow and be competitive. The company grows based on management's commitment to religious values such as Islamic values and business spirit, so that the company has a strong soul (Baldo, 2009). Meanwhile, studies that found no evidence were revealed (Cheng and Courtenay, 2006). They state that as good as anything or as bad as any corporate governance is meaningless for the implementation of CSR. It is suspected that the company has a commitment to continue implementing CSR.

The purpose of this study is to get a full explanation of the implementation of essential awareness-based CSR in Islamic banking in Indonesia. It is believed that 
corporate governance, financial performance and the spirit of faith-based on religious values will be able to complete the answer "why is Islamic banking implementing CSR based on essential awareness?

In order to obtain a complete explanation of the phenomenon of the implementation of CSR in Islamic banks in Indonesia, the method used is the concept of essential awareness. Awareness is a reflection of spiritual commitment. That is, companies must be responsible for the social and environmental consequences of their activities (Mostovicz et al., 2009) and are not limited to reducing community complaints or resistance or meeting the demands of government regulations.

\section{THEORETICAL REVIEW}

Some theories related to CSR disclosure such as stakeholder theory and legitimacy theory. The view of stakeholder theory was initiated by (Freeman, 1984) that CSR activities are carried out to accommodate the wants and needs of stakeholders. So that companies can move well (Luoma-aho et al., 2010; Maharaj, 2008; Money et al., 2012). The strength of this theory is able to bridge ethics and capitalism. In addition, it is able to combine social contracts and company decisions so as to increase the value of the company (Beckman et al., 2016). While the legitimacy theory is only able to explain that the company operates in a changing external environment. Therefore, they try to make sure that their behavior is in accordance with the boundaries and norms of society. In addition, legitimacy theory focuses on interactions between companies and society (Lanis and Richardson, 2013; Luke et al., 2013; Mohamed et al., 2014).

Although stakeholder theory and legitimacy theory have inspired many researchers to review the phenomenon of CSR implementation. However, there has not been a comparison of the values of giving awareness. CSR must also be interpreted as a movement or a culture of giving and not being pretended to be fake. Indeed, running CSR must be framed with a sacred mission, love, sincere, spontaneous, expressed with joy, and not experiencing fatigue. It is believed, the movement or culture of giving becomes an adhesive and can reduce complaint tension between companies and stakeholders and can meet the demands of government regulations.

It is ensured, the culture of giving of essential awareness will get rewards of its own deeds from Allah, as mentioned in the Qur'an: "whoever does good, even though it is as heavy as zarrah, surely he will see the reward, and whoever does evil even though zarrah though he will undoubtedly see his reply, "(Surat al-Zalzaalah: 7-8). Looking at these verses, we are prosecuted and asked about their accountability before Him. In order to realize this awareness, especially moral awareness, it should be followed by good behavior too.

The awareness or culture of giving is good behavior and holy mission. Behavior is not good to do, unless the person really does not want to know about goodness anymore, and does not want to distinguish between the good and the bad so that God closes his eyes. Therefore, the implementation of CSR is awareness as the mandate of God to build and maintain human welfare.

Such behavior has actually been reminded in the Qur'an, namely: "Indeed the evilhearted or as bad as the creatures besides Allah SWT are those who are deaf and dumb," (QS. Al-Anfal: 22). That is people who cannot hear things that are good and do not know 
things that are right and good. Something right and good have been proven to be able to improve the efficiency and performance of the company, especially financial performance and stronger stakeholder trust by the company (Andrikopoulos et al., 2014; Angelia and Suryaningsih, 2015).

Although previous studies have produced a lot of information about the implementation of CSR, it is still limited which reveals the motivation of CSR. This study seeks to uncover CSR motivations carried out from different sides, namely from a portrait of intrinsic sharia-based awareness in Islamic banking in Indonesia. (Aribi et al., 2010) states that there are significant differences between Islamic financial institutions and conventional financial institutions in implementing CSR.

There is an impression, companies that are financially capable do not necessarily want to implement CSR. Meanwhile, companies that want to be financially capable of sharing some of their assets. Isn't financial performance a portrait that the company has been well managed and qualified? If that is true, companies that have financial capacity should be able to make CSR as a giving movement.

In other words, God has affirmed that there are groups of people whose deeds are in vain if they are not beneficial to people. Say (Muhammad), "Do we need to tell you about the person who loses the most from his actions?" (That is) those who are in vain in the life of the world, while they think they have done their best. "(QS. Al-Kahf: $103-104)$. This verse reminds us that it is a loss if the company does not share. To survive the loss, the company must also save themselves and try to save the community with faith and good deeds through CSR. Imam Ali bin Abi Tholib once said, "The truth is hard but the result is beautiful. And sleaze is mild but the result is misery. "Conveying the truth is not an easy thing. Inviting to the truth is also not a light thing. Look at the prophets, they sincerely invited the truth but were accused of being crazy or witches. Some were chided, thrown and even killed. The best people are human beings who benefit others (HR Thabrani).

Human existence is actually determined by its usefulness to others. Is he useful for others, or even vice versa becomes a parasite for others? Every deed will return to the people who act. As we provide benefits to others, the benefits will return for the good of ourselves and vice versa. Allah has said that "If you do good, you actually do good for yourself" (Surat al-Isra: 7).

The importance of financial performance as a portrait of the company that it has been managed well and has quality. To achieve financial performance excellence, companies should run compliance, conduct ethical business and have CSR awareness as a form of good citizens. Moreover, the system and culture continue to be developed in accordance with the demands and business changes to realize the aspirations for advanced Islamic banking, to be loved by its customers, to be competitive in the industry and to become a role model for the company.Financial performance is not enough to uncover awareness of CSR implementation. If only, spirit became a nutria or flavoring for implementing CSR in Islamic banks. Believed, with ihsan spirit always give the best in every job we do. Because the essence of ihsan spirit contains meaning, namely improving, better and better. People who have the spirit of success always improve the ordinary things into better conditions, and if the improvement is carried out continuously, it will eventually bring it to the best (Yahya, 2013). 


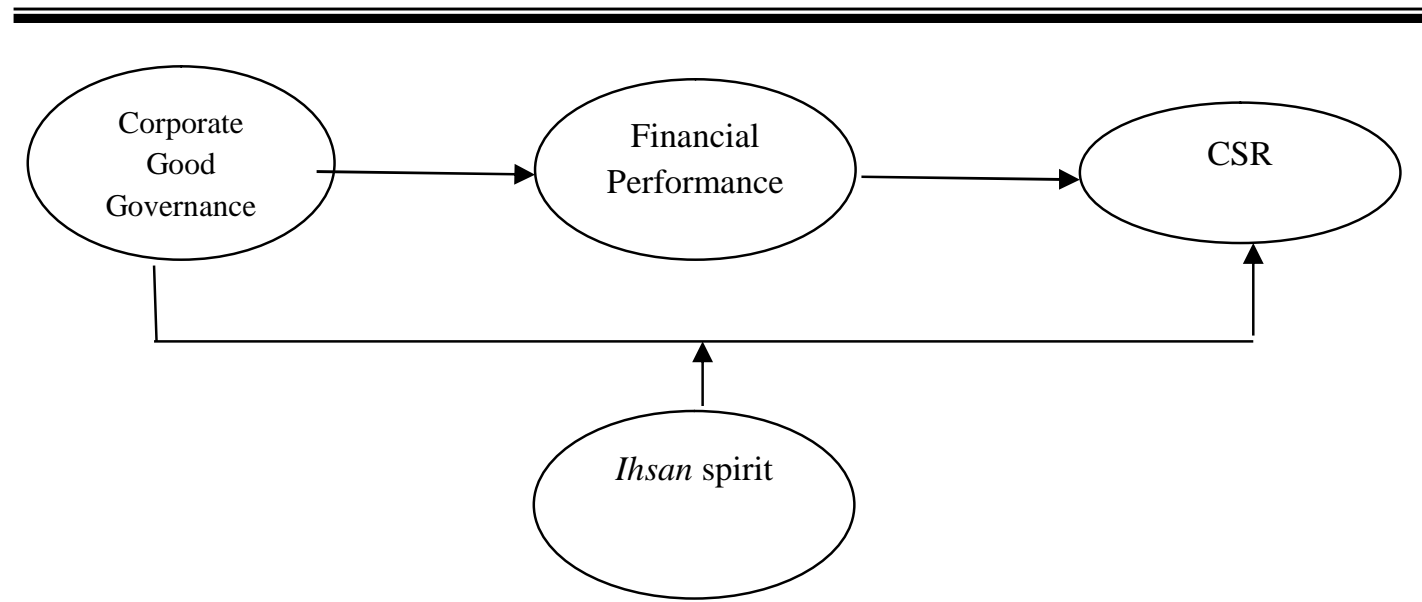

Figure 1. Conceptual Framework

\section{RESEARCH METHODS}

The sampling technique uses purposive sampling. The number of samples is set at 6 people in each Islamic bank, among managers from 12 Islamic banks in Indonesia. This study was conducted in 2016 and the questionnaires collected amounted to 62 respondents. All variables used in this study were measured using a 1-5 Likert scale. Respondents are given the freedom to determine their opinions or opinions according to their experiences.

Before the questionnaire was distributed to respondents, a trial was first carried out. Next, the validity test and reliability test are carried out. The goal is to know the quality of the question items from the list of questions that will be used in this study. Measuring validity is done by making bivariate correlations between each indicator score and total construct score, with a Pearson correlation coefficient. The indicator is said to be valid if the positive correlation coefficient and the minimum amount are 0.30 . Then, the reliability test shows the consistency and stability of a score or scale of measurement. Instruments can be said to be reliable or reliable if they have an alpha coefficient of 0.60 or more (Solimun, 2012).

After the data is collected, data editing is done to find out data errors, making it easier to enter data into the tabulation sheet. After tabulating the data, the data analysis is then carried out. Before the data is analyzed, the classic assumption test is carried out, namely the linear assumption test. Finally, data analysis is carried out through generalized structured component analysis (GSCA) software (Hwang, 2009; Tenenhaus, 2008, quoted by Solimun, 2012). Measurement of latent variables uses indicators that are different from previous researchers, namely using sharia concepts: (1) governance with indicators siddiq, tabligh, amanah and fathanah, (2) CSR with indicators of zakat, qordhul hasan, social and charitable activities, environment, and community involvement, (3) financial performance with financing quality indicators, risk financing attitudes, and sharia profitability, and (4) spirit of ihsan is to improve (ahsana), better (yuhsinu), and best (ihsanan). 


\section{DISCUSSION AND FINDINGS}

Measurement Profile of Research Variables. The estimated coefficient value on loading shows the weight of each indicator as a measure of each latent variable. The mean value shows the actual condition of each indicator according to the respondent's perception or perception. Recapitulation of estimated factor weight values and mean (mean) of each indicator can be seen in each of the following Tables.

Table 1. The Weight Value of Factor and Average of Corporate Governance Variable

\begin{tabular}{|c|c|c|c|c|}
\hline \multirow{2}{*}{ Variable } & \multirow{2}{*}{ Indicators } & \multirow{2}{*}{ Weight of factor } & \multicolumn{2}{|c|}{ Average (Mean) } \\
\hline & & & Indicators & Variable \\
\hline & Siddiq, (X1.1) & 0.622 & 4.45 & \multirow{4}{*}{4.45} \\
\hline \multirow{3}{*}{$\begin{array}{l}\text { Corporate Good } \\
\text { Governance (X1) }\end{array}$} & Tabligh, (X1.2) & 0.640 & 4.35 & \\
\hline & Amanah (X1.3) & 0.799 & 4.49 & \\
\hline & Fathanah (X1.4) & $\mathbf{0 . 8 2 0}$ & 4.52 & \\
\hline
\end{tabular}

Notes: thickening of numbers is the most important indicator

The mean value obtained by the corporate governance variable is 4.45 and the most powerful indicator in reflecting corporate governance in Islamic banking is the indicator of fathanah of 0.820 . That is, personal management understands, understands and lives more deeply in everything that is their duty and obligation. Then, successively following indicators are trust, tabligh, and siddig.

Table 2. The Weight Value of Factor and Average of Financial Performance

\begin{tabular}{clccc}
\hline \multirow{2}{*}{ Variable } & \multicolumn{2}{c}{ Indicators } & Weight of & \multicolumn{2}{c}{ Average (Mean) } \\
\cline { 4 - 5 } & factor & Indicators & Variable \\
\hline \multirow{2}{*}{ Financial } & SKP (Y1.1) & 0.762 & 4.27 & \multirow{2}{*}{ Perf } \\
Performance (Y1) & SRP (Y1.2) & $\mathbf{0 . 8 4 9}$ & $\mathbf{4 . 3 6}$ & \multirow{4}{*}{ Profitability (Y1.3) } \\
& & 0.389 & 3.42 & \\
\hline
\end{tabular}

Notes: thickening of numbers is the most important indicator

The mean value obtained by the financial performance variable is 4.17 and the most powerful indicator in reflecting financial performance in Islamic banking is the attitude indicator of risk financing (SRP) of 0.849 , and subsequently the quality financing attitude indicator (SKP). While the smallest indicator is profitability revealed in the statement of net profit after zakat.

Table 3. The Weight Value of Factor and Average of Ihsan Spirit

\begin{tabular}{ccccc}
\hline \multirow{2}{*}{ Variable } & \multirow{2}{*}{ Indicators } & Weight of & \multicolumn{2}{c}{ Average (Mean) } \\
\cline { 3 - 5 } & & factor & Indicators & Variable \\
\hline \multirow{3}{*}{ Ihsan Spirit } & Ahsana, (M1.1) & $\mathbf{0 . 8 7 3}$ & $\mathbf{4 . 3 8}$ & \multirow{4}{*}{.31 } \\
& Yuhsinu, (M1.2) & 0.673 & 4.28 & \\
& Ihsanan (M1.3) & 0.704 & 4.26 & \\
\hline
\end{tabular}

Notes: thickening of numbers is the most important indicator

The mean value obtained by spirit ihsan variable is 4.31 and the highest estimate value for loading among eleven items of work questions is worship as much as 0.873 
which is attached to the ahsana indicator, then the indicator that needs improvement is ihsana danyuhsinu.

Table 4. The Weight Value of Factor and Average of CSR Variable

\begin{tabular}{llccc}
\hline \multirow{2}{*}{ Variable } & \multicolumn{1}{c}{ Indicators } & Weight of & \multicolumn{2}{c}{ Average (Mean) } \\
\cline { 4 - 5 } & Zactor & Indicators & Variable \\
\hline \multirow{3}{*}{$\begin{array}{l}\text { Zorporate Social (Y2.1) } \\
\text { Responsibility }\end{array}$} & Qordhul hasan (Y2.2) & 0.616 & 4.30 & \\
& Social and charitable activities & 0.778 & 4.17 & \\
& (Y2.3) & 0.867 & 4.25 & $\mathbf{4 . 2 4}$ \\
& Environment (Y2.4) & $\mathbf{0 . 8 8 3}$ & $\mathbf{4 . 3 1}$ & \\
& Community involvement & 0.785 & 4.16 & \\
& $(Y 2.5)$ & &
\end{tabular}

Notes: thickening of numbers is the most important indicator

The mean value obtained by CSR variable is 4.24 and the most powerful indicator in reflecting CSR in Islamic banking is the environmental indicator 0.883 If viewed from the actual conditions the environmental indicator is good if used as a measure or indicator of CSR variables so that it must be maintained. However, the indicator of zakat needs to be a concern of Islamic banking management.

Classical Assumption Test, Model Goodness and Hypothesis Testing. The results of testing the classical linear assumption show that all relationships between variables are linear, so the linear assumption is fulfilled because it is below 0.05 .

Table 5. The Test Results for Linearity Assumptions

\begin{tabular}{llll}
\hline \multicolumn{2}{c}{ Inter-Variable Relationships } & \multicolumn{1}{c}{ Test Result } & Decision \\
\hline $\begin{array}{l}\text { Corporate Good } \\
\text { Governance }\end{array}$ & CSR & $\begin{array}{l}\text { Sig linear model 0,000 } \\
\text { 0,05 (linear model) }\end{array}$ & Linear \\
$\begin{array}{l}\text { Corporate Good } \\
\text { Governance }\end{array}$ & Financial & Sig linear model 0,000 & \\
Financial Performance & Cerformance & 0,05 (linear model) & Linear \\
& & Sig linear model 0,002 & \\
Ihsan Spirit & CSR & 0,05 (linear model) & Linear \\
& & Sig linear model 0,000 & \\
& & 0,05 (linear model) & Linear \\
\hline
\end{tabular}

Notes: significant linier model 0.05

GSCA provides a structural model size and overall model seen from the values of FIT, AFIT, GFI (Unweighted Least-Squares), and SRMR (Standardized Root Mean Square Residual). 
Table 6. Evaluation of Goodness of FIT Structural Models and Overall Models of the GSCA

\begin{tabular}{cc}
\hline \multicolumn{3}{c}{ Model Fit } \\
\hline FIT & 0.595 \\
AFIT & 0.475 \\
GFI & 0.801 \\
SRMR & 0.089
\end{tabular}

Notes: FIT ranges from 0 to 1; AFIT (Adjusted FIT) similar to R2 adjusted in regression analysis; The GFI values close to 1 and the SRMR values close to 0 may be taken as indicative of good fit.

The FIT value obtained by 0.595 means that the former model can explain the existing variables of 59.5 percent. The diversity of corporate governance variables, financial performance, spirituality, and CSR can be explained by the model by 59.5 percent, and the remaining 40.5 percent can be explained by other variables outside the model. It can be concluded that this study model is said to have good accuracy or model accuracy. GFI results of data analysis obtained a value of 0.801 , then the model formed can be said to be appropriate or good. Testing of structural models and hypotheses is done to determine the relationship between latent variables in this study. From the output of the GSCA model, testing structural models and hypotheses are done by looking at the estimated path coefficient and critical point value $(\mathrm{CR} *)$ which is significant at the 95 percent confidence level and the standard value of $t$ is 1.96 .

Table 7. Path Coefficient Analysis Results

\begin{tabular}{|c|c|c|c|c|}
\hline Model & $\begin{array}{l}\text { Inter-Variable } \\
\text { Relationships }\end{array}$ & $\begin{array}{c}\text { Path } \\
\text { coefficient }\end{array}$ & $\begin{array}{c}\mathrm{CR} \\
\text { (t-test) }\end{array}$ & Description \\
\hline \multirow{5}{*}{$\begin{array}{l}\text { With Mediation and } \\
\text { Moderation Variables }\end{array}$} & $\operatorname{TKP}(\mathrm{X}) \rightarrow \mathrm{K}, \mathrm{Keu}(\mathrm{Y} 1)$ & 0.522 & $1.98^{*}$ & Significant \\
\hline & $\operatorname{TKP}(\mathrm{X}) \rightarrow \mathrm{CSR}(\mathrm{Y} 2)$ & 0.792 & 1.1 & Insignificant \\
\hline & $\mathrm{K}, \mathrm{Keu}(\mathrm{Y} 1) \rightarrow \mathrm{CSR}(\mathrm{Y} 2)$ & 0.323 & $4.95^{*}$ & Significant \\
\hline & S.Ihsan $(\mathrm{M}) \rightarrow$ CSR $(\mathrm{Y} 2)$ & 1.334 & $3.56^{*}$ & Significant \\
\hline & $\begin{array}{l}\operatorname{TKP}(\mathrm{X})^{*} \text { Ihsan Spirit (M) } \\
\rightarrow \text { CSR (Y2) }\end{array}$ & 1.436 & $3.01^{*}$ & Significant \\
\hline $\begin{array}{l}\text { Without Mediation } \\
\text { and Moderation } \\
\text { Variables }\end{array}$ & $\operatorname{TKP}(\mathrm{X})$-> CSR (Y2) & 0.660 & $6.85^{*}$ & Significant \\
\hline
\end{tabular}

Notes: *signifikan pada $\alpha=0.05$

Discussion. The first model, investigating corporate governance relationships with CSR without the role of financial performance and the role of spirit ihsan. The findings show that the better corporate governance the better the implementation of CSR with assumptions without the role of financial performance and the role of spirit ihsan in Islamic banking in Indonesia. This is suspected by the management's ability to manage the bank based on sharia values, namely smart (fathanah), trustworthiness (trust), openness (tabligh), and secarabenar (siddiq), thus encouraging corporate awareness to carry out CSR reflected by zakat, qordhul hasan, social activities and charity, the environment, and involvement in the community. 
Recognized or not, intelligent management (fathanah) is more prominent in reflecting Islamic banking governance. Governance with the shield of intelligent concepts (fathanah) is a skill that must be possessed by bank management, namely competitive intelligence such as networking, research skills and analytical abilities (Strauss and Toit, 2010). After the intelligent concept (fathanah) is strengthened, the next concept is to be trusted (trust).

A strong bank is a bank that maintains trustworthiness and trustworthiness. To become a strong bank, efficient governance is needed which results in market appreciation and increases investor confidence (Rocca, 2007). Hopefully, management will not only become an obligation that must be carried out by the company but be part of the corporate culture to achieve sustainability and business resilience.

The balance and resilience of the company requires governance characterized by openness (tabligh). The power of openness is nothing to hide. As a bank that has a sharia typology, it always strives to maintain objectivity in carrying out its business activities. In addition, by providing material information that is relevant to the needs of shareholders and stakeholders, and ensuring that information is provided in a timely, adequate, clear, accurate, and easily accessible manner.

It seems that the implementation of the pillar correctly (siddiq) is still relatively low in reflecting the management of Islamic banking. It is estimated that there are still some elements that tend to be contaminated by conventional culture and the commitment to manage the bank well is still low. Supposedly, the application of the pillar secarabenar (siddiq) is a commitment of Islamic banking in reflecting a form of corporate accountability to shareholders and stakeholders that the bank is well-managed and qualified. In fact, good and right governance can help increase productivity (Tian and Twite, 2011).

It can be ascertained that management is characterized by intelligence (fathanah), trust (trust), openness (tabligh), and correctly (siddiq) can reduce resistance or complaints between management and stakeholders and stakeholders. As a result, good and quality Islamic banking management in Indonesia will strengthen awareness of CSR implementation.

Empirical reality, environment is the most dominant reflection in the implementation of Islamic banking CSR in Indonesia. There is a tendency, Islamic banking management seeks to encourage the economic life of local communities and realize that business sustainability is determined by the environment. Having the importance of the environment can be seen as conscious nutrition by companies in realizing commitment to economic, ethical and voluntary legal responsibility for economic action. The implication is that it can reduce resistance or complaints between management and stakeholders.

Efforts to maintain tension of resistance or complain, Islamic banking always carries out social and charitable activities. This was revealed from good relations with the surrounding community so that they received significant social benefits. Applying CSR properly and involving the community can reduce resistance in the community. Therefore, doing CSR properly is a movement of worship and awareness.

It is not enough to just rely on social and charitable activities, Islamic banking continues to increase qordhul hasan as a reflection of CSR implementation. CSR characterized by qordhul hasan is voluntary assistance, such as providing financing based on agreements and channeling funds to the poor. It is certain that the pillars of social and 
charitable activities and qordhul have been able to reduce resistance or complain between companies and stakeholders.

Uniquely, zakat as a reflection of the implementation of CSR in Islamic banking is the last priority. Zakat is interpreted as an offering of awareness and obligation in realizing CSR in Islamic banking. Indeed, zakat must be interpreted as an important achievement for companies that continue to commit to CSR. The company's commitment to carry out CSR in a sustainable manner continues to bring many benefits such as social investment, strengthening financial performance, increasing corporate accountability, and reputation in the eyes of investors, and reducing resistance from surrounding communities. Even CSR can reduce information asymmetry (information asymmetry) between management and investors (Article et al., 2010).

The results of this study have similarities as revealed by (Esa et al., 2012; Sun et al., 2010) that the better corporate governance the better the implementation of Islamic bank CSR. This means that the management of Islamic banks that are characterized by siddiq, tabligh, trusteeship and fathanah can produce Islamic corporate values and managerial culture, thereby strengthening the implementation of CSR based on essential awareness by Islamic banking in Indonesia. The implementation of CSR characterized by zakat, qordhul hasan, social and charitable activities, the environment, and involvement in society is a foundation of essential awareness.

Giving awareness is closely related to obligation. The obligation to God, oneself, fellow human beings, society, and the universe. The implication of essential awareness is the ability to perceive, interact, and communicate with the environment and with others in an integrated and sustainable manner.

Islamic banks realize that behind giving there is the power of giving, namely new enthusiasm, happiness and being in the hills of victory. (McKinnon, 2014) states that for prosperity and happiness to always be with us, we have giving behavior. Giving creates a symbiotic relationship. Both parties benefited. The recipient benefits from the giving of the company, and the company receives true benefits because it has become a giver. The more companies give the more enthusiasm, energy, age, and excitement the company gets from the life of the company. The culture of giving is a form of awareness to get the potential that can be sold while improving the world through its actions such as the culture of CSR. Cultural giving will be strong and thrive when followed by moral values or organizational ethics (Mostovicz et al., 2012; Reverte, 2009; Reynolds and Yuthas, 2008). Essential awareness-based CSR can be interpreted as an offering by sharia banking companies to God, society, and ecosystems and is believed to be free from complains or resistance from society and the government and does not appear cosmetic. Unlike CSR based on stakeholder theory and legitimacy, theory tends to be cosmetic. Stake-based CSR new theory is limited to accommodating the wants and needs of stakeholders. Seain, trying to combine social contracts and company decisions so that the company's value is good (Beckman et al., 2016). In fact, stakeholder theory has not yet been found proof of the giving power of some of the assets owned by the company. Likewise, the legitimacy theory can only protect the interaction between the company and society within the boundaries and norms of society so that it can be ascertained that the power of giving has not been found.

Hasn't Allah ever reminded in his words in the Qur'an, "The parable of those who infuse their wealth in the way of Allah is like a seed that grows 70 stalks, on each stem, 
there are 100 seeds? Allah multiplies for whomever He desires and Allah is Extensive, All-Knowing, "(Surat al-Baqarah: 261). Logically it is impossible if we remove our assets but our assets are not reduced but instead multiplied. This is one of the secrets of Allah and only Allah is the All-Knowing, the All-Things.

In other words, God advised, "And what harm will befall them if they believe in Allah SWT and the Last Day, and give away some of what Allah has given them? And Allah knows what they do, "(Surat an-Nisa: 39). From this verse, it can be taken the meaning that those who donate their property will not have any losses.

This study differs findings (Cheng and Courtenay, 2006) that CSR is not determined by corporate governance. This is indicated by differences in the use of corporate governance indicators and CSR indicators. This study was conducted in Islamic banking. While previous studies were attached to non-Islamic banking companies. Therefore, the results of this study cannot be generalized to different objects.

The second model, investigates governance relationships with CSR through the role of financial performance. Financial performance plays a strong role and means mediating governance relationships with CSR. This means that the better corporate governance the better the financial performance and the better the CSR of sharia banking. Financial performance is identified as complete mediation. Apparently, when financial performance was put in as a mediating variable, it was revealed that CSR was not determined by corporate governance. This means that the size of corporate governance is not a determining factor in the implementation of CSR in Islamic banking. It is believed, governance relations with CSR will be meaningful if through financial performance. Thus the term financial performance has a strong and meaningful role in the governance of Islamic banks with CSR. Financial performance is a reflection that the company has been well managed and qualified and can finance the implementation of CSR.

Indicators of siddiq, tabligh, trust and fathanah are corporate governance shields that encourage financial performance and are perceived well by respondents. Providing services with precision, serving with full courtesy, full of responsibility for work, professionals in working and building a competitive business core and working smart. This is a manifestation of the meaning of the fathanah. Not enough with fathanah to measure the success of corporate governance, but trust is needed. Ideally, managing Islamic banks begins to build communication especially in intra-management so that mutual trust is solid and at the same time use the principles of prudence and prioritize honesty values so that customers remain confident and confident in Islamic banking services.

Openness (tablig) becomes a necessity in the management of Islamic banks. Openness can be interpreted as noble behavior in managing Islamic banks in which there are messages of moral and ethical values. (Efferin, 2016) states that there is the ability to listen to others with awareness. A conscious model of openness to listening to others is a sharia-based governance feature. In fact, companies must open themselves to attract others and the company will be freed by resistance or stakeholder complaints.

In addition to using the principle of prudence and honesty, it is no less important to manage Islamic banks they use the principle correctly (siddiq). Even though Siddiq is low, it does not mean the sharia bank's sacred mission is blurred or lost. Whatever work activities or professions that run, the universal holy mission by Islamic banks is to carry 
out the mandate of Allah SWT to build and maintain human welfare through work (Iriyanto, 2015).

This study has similarities as has been revealed by (Bhagat and Bolton, 2008; Klapper and Love, 2004; Nelson, 2005; Reddy et al., 2010) that the better the management the better the financial performance of the company. In practice, financial risk is the most important factor in measuring financial performance without ignoring other indicators. The ability to manage a bank well can strengthen financial performance and can reduce resistance or complaints between management and stakeholders.

This risk is addressed with good risk management. This risk management can be initiated by screening (sreening) prospective customers and investments to be financed. Thus, the risk management of financing in Islamic banks is strongly related to the character of the customer and the risk of investment. Character risk is related to matters related to the customer's character. While investment risk is related to the character of the investment to be financed. Therefore, the lower the financial risk the stronger the financial performance.

There is a tendency for Islamic banking to finance productive and quality investments. Funded investment is a profitable company investment and shows the cash flow trend from year to year has increased and has the smallest risk. Productive and good quality financing patterns can strengthen financial performance such as profitability. Benefits after zakat are issued are a characteristic feature of measuring profitability in Islamic banks. Zakat is the washing of company assets offered to God. Islamic banks are beginning to realize that the acquisition of profits can not be separated from the mercy of love from God in the form of profitability.

The financial performance obtained at this time is the result of good and quality governance in the previous period and useful work will now be enjoyed tomorrow. Firmly the word of God is affirmed: "Indeed, Allah likes people who fight in His way in a regular line as if they are like a solidly structured building" (Surah ash-Shaf: 4). What a disadvantage the company is if it is not managed properly and is of good quality. As the word of God means "For the sake of time, indeed all men are in loss except those who believe and do good deeds". (Surah al-Asr: 1-3).

This study found evidence that better financial performance the better the implementation of CSR by Islamic banking. There are similarities in the results of studies as revealed by them (Beurden, 2008; Celine, 2011; "Corporate Social Responsibility A Firm Perspective Theory 2001.pdf," n.d.) that the better financial performance the better the implementation of CSR. Although there are similarities in the results of studies with previous researchers, it has not been found that the meaning of giving out of some assets is a symbol of CSR implementation. It is truly noble to give to others, especially to those who are in need. Giving brings a new spirit to the business activities carried out. There is no more separation when thinking business and when thinking social.

Full awareness and holy intention to do positive things like CSR have become an integral part of the life aspects of Islamic banks. In addition, good deeds will be a source of happiness for all members of the organization because what they do is no longer based solely on selfish intentions. In other words, the goal of doing good if packaged in a smart and creative manner will produce a variety of positive effects both for the company, its members, society and the environment (Efferin, 2016). 
The concern will be more fertile if we always instill in mind that we are very caring people. If we feel that people are very caring, then we will be happy to take environmental and poverty care actions. The concern for the environment may be very simple and easy to do, as is the custom done by Islamic banks, namely providing scholarships for the poor, planting trees, building clean water facilities and so on. If it continues to be done, then gradually that concern will become our breath and feel happier.

The motive stated by the respondents was that the implementation of CSR was not limited to fulfilling the form of the company's commitment to its stakeholders, which had been involved in the management of the company. As revealed by stakeholder theory initiated by (Freeman, 1984) that CSR activities are carried out to accommodate the desires and needs of stakeholders (stakeholders) so that the company can move well with all the support of these stakeholders ("Corporate social disclosure in the context of national cultures and stakeholder theory, "2010; Jamali, 2008). That is, the spirit of this theory is that the company is not seen by one hand but in many hands. While legitimacy theory explains that companies operate in an external environment that changes constantly and they try to ensure that their behavior is in accordance with the boundaries and norms of society. Legitimacy theory focuses on interactions between companies and communities (Archel et al., 2009; Ieng et al., 2013; Lanis and Richardson, 2013).

Evidently, stakeholder theory and the theory of legitimacy still have a void of explanations that have not presented aspects of culture and religious values. Therefore, to fill the gap in the void of explanation related to disclosure of CSR highlighted through intrinsic awareness. Essential awareness-based CSR is able to accommodate community pluralism in the cultural and religious dimensions. Apparently, Islamic banking presents a manifestation of the company's concern for those who are poor, helpless and suffer from natural disasters. While respondents are committed to helping the government in overcoming social and environmental problems. This has been reflected in indicators of social and charitable activities. Therefore, the construction of awareness values based on sharia values can reduce resistance and complaints between companies and stakeholders.

And the last model, investigating governance relationships with CSR through the role of spirit ihsan. Empirical facts, spirit of ihsan have a significant role in strengthening corporate governance relationships with CSR in Islamic banking. That is, the better the spirit of success the stronger the corporate governance relationship with CSR in Islamic banking. Spirit of identity identified as quasi (quasi-moderation) is a moderating variable between corporate governance and CSR variables where management interacts with CSR as well as being a variable predictor.

People who have a spirit of ihsan always improve ordinary things into a better condition, and if the improvement is done continuously, then it will eventually bring it to be the best (Yahya, 20130). So, if you talk about ihsan, then the continuous improvement is a must. Continuous improvement in order to offer the best to Him.

The ihsany spirit is reflected by the power of spirit ahsana, yuhsinu, and ihsanan. The spiritual commitment indicated by people has a meaningful role when compared to yuhsinu, and ihsanan. Because the meaning of ahsan is someone's spiritual commitment to improve (ahsana) work. There is a tendency for Islamic banking to always make improvements in the implementation of corporate governance and implementing CSR. It is believed that the implementation of corporate governance and implementing CSR in 
Islamic banking is good. Evidently, there is the role of ahsanadalam to improve the noble work. Sincerity improves work solely because of God. Therefore, work is worship.

The ihsanan indicator has a meaningful role after ahsanadalam reflects spirit ihsan. Because work is part of worship to God, then even in work we must offer the best (ihsanan). There is a basic belief that must be possessed by Islamic banking people to always offer the best (ihsanan) in conducting corporate governance and CSR.

To achieve the best (ihsanan) or (excellence) is a journey that never ends (Yahya, 2013). This means that the implementation of corporate governance and the implementation of good and quality CSR must be interpreted as a victory hill compared to companies that do not rely on religious values. The series of victory hills to the hill of victory is an achievement which in turn encourages Islamic banking to realize sustainable growth. Therefore, success reflects the strength of corporate governance relationships with CSR.

The last one is the Yuhsinu indicator. It was found, the indicator of the yuhsinu (better) seemed to give less meaningful role when compared with ahsanadan ihsanan. That is, yuhsinu as a buffer or strengthening the implementation of corporate governance and CSR has not given much meaning so that the power of the yuhsinus is needed as a form of reflection on spirit ihsan for Islamic banking.

This study supports the statement of (Yahya, 2013) that spirit ihsan is the foundation of the company's philosophy that the company always does the best. That is, a basic spirit for the company to always give the best in every job done. Therefore, the best offerings are manifestations of consciousness. (Mostovicz et al., 2009) states that awareness is a reflection of spiritual commitment. That is, companies must be responsible for the social and environmental consequences of their activities.

The results of the portrait of the concept of essential awareness reveal that corporate governance and CSR are not limited to the interests of pursuing utilities or the use of resources in the pursuit of growth in corporate values as revealed by conventional theories. Portrait of essential awareness concept is not limited to merely accommodating interests and needs in order to get support from stakeholders, such as sound by stakeholder theory and not limited to explaining the behavior of companies operating in accordance with the boundaries and norms of society such as the legitimacy theory. However, the concept of essential awareness is able to juxtapose sharia values related to aspects of business objectives, culture and business ethics. (Ever Perera, 1989) and (Hofstede, 1983) state how the adoption of CSR, if highlighted from a cultural and religious perspective, will be strong and quality. For Islamic banks, spirit ihsan is power in doing noble work such as managing a company and implementing CSR.

This study found that corporate governance interaction with spirit ihsan was positive and significant. This means that better corporate governance is accompanied by the power of spirit to strengthen the implementation of CSR in Islamic banking. The mix of governance with spirit ihsan is new construction in strengthening the implementation of CSR. Besides that, it can also be interpreted as an ideology characterized by cultural values and business ethics. The core ideology becomes a compass and the basis of every strategic, system and business goal developed by the company. Idealism continues to inspire everyone in the organization to navigate the turbulent changes in the business environment from time to time (Yahya, 2013). The essence of ideology is the ultimate 
awareness in realizing the great ideals of giving the best to the nation and the state and the universe like the implementation of CSR.

Indeed, it cannot be avoided, there is still an impression in certain communities that the implementation of CSR by Islamic banks seems to only pursue reputation and popularity. Accepted or not, Islamic banks build a reputation and popularity based on intrinsic values of consciousness. Reputation or good name can not just happen. Rather it must be built and fought with high awareness (Iriyanto, 2015). Like building reputation requires a strong foundation with ihsan spirit. The pillars and walls must also come from quality materials, so they can stand tall and sturdy. After that, the doors and windows must also be open, so that the fan air light can freely circulate. In addition, the roof must also be selected from materials that are able to provide shade and comfort for its residents. Therefore, the foundation of a reputation is integrity.

In essence, the implementation of CSR in Islamic banking based on the values of intrinsic awareness as a reflection of offerings to the nation and the state and the universe, not only in an effort to penetrate sin and reduce resistance and complaining stakeholders. Therefore, through the corporate governance mix and the spirit to strengthen the implementation of CSR and not be impressed with cosmetics.

As a theoretical contribution in this study is to improve or complement the existing CSR theory with the theory of awareness-based CSR disclosure. Then, the practical contribution of the results of this study is to apply real practice or better improve existing practices based on awareness.

\section{CONCLUSION}

The face of governance and CSR by Islamic banks in Indonesia shows a different face from the face of governance and CSR by conventional banks and companies. The management of Islamic banks, which is reflected in the siddiq, tabligh, amanah, and fathanah, is able to create Islamic corporate values and managerial culture, thus strengthening the implementation of CSR based on essential awareness by Islamic banking in Indonesia. The implementation of CSR characterized by zakat, qordhul hasan, social and charitable activities, the environment, and involvement in society is a foundation of essential awareness. Therefore, good and quality governance will strengthen the implementation of CSR.

Behind giving is the giving power which is the awareness of giving from some of the assets owned. The more companies give, the more new enthusiasm into business activities are carried out, energy, age, and excitement that the company gets from the life of the company. There is no more separation when thinking about business and when to think socially. The culture of giving is a form of awareness to get the potential that can be sold while improving the world through its actions such as the culture of CSR. Full awareness and holy intention to do positive things like CSR have become an integral part of the life aspects of Islamic banks.

Between governance and CSR will mean if through financial performance. Thus the power of financial performance has a strong and meaningful role between governance and CSR attachments. Financial performance is a reflection that the company has been wellmanaged and qualified and can finance the implementation of CSR. The financial 
performance currently obtained is the result of good and quality management in the previous period and the holy mission will be enjoyed later in the day.

Financial performance is not sufficient in governance relations with CSR if it is not accompanied by spirit ihsan foundation. So great is the spirit of spirit or spiritual commitment that it will improve ordinary things to be extraordinary. Furthermore, if the improvement is carried out continuously, it will eventually bring it to the best. To achieve the best (ihsan) or (excellence) is a journey that never ends. This means that the implementation of corporate governance and the implementation of good and quality CSR must be interpreted as a victory hill compared to companies that do not rely on ihsan values. The series of victory hills to the hill of victory is an achievement which in turn encourages Islamic banking to realize sustainable growth. The spirit reflects the strength of corporate governance relationships with CSR. Therefore, the implementation of CSR by Islamic banks must not be limited to reducing resistance or complaining, cosmetics, pursuing reputation and popularity, but must be seen as essential awareness.

The information we obtain is still limited because it only relies on information from the questionnaire statement. We have not conducted in-depth interviews with respondents. However, through this questionnaire, we have been able to explain objectively the phenomenon of this study.

\section{REFERENCES}

Al-Qur'an dan Terjemahan. (2016) Jakarta: Yayasan Penyelenggara Penerjemah Al Qur'an Kementrian Agama Republik Indonesia.

Afifah, N., dan Asnan, A. (2015). The Impact of Corporate Social Responsibility, Service Experience and Intercultural Competence on Customer Company Identification , Customer Satisfaction and Customer Loyalty (Case Study: PDAM Tirta Khatulistiwa Pontianak West Kalimantan), 211(September), 277-284. http://doi.org/10.1016/j.sbspro.2015.11.035.

Andrews, N. (2016). Challenges of corporate social responsibility ( CSR ) in domestic settings : An exploration of mining regulation vis-à-vis CSR in Ghana. Resources Policy, 47(40), 9-17. http://doi.org/10.1016/j.resourpol.2015.11.001.

Archel, P., Husillos, J., Larrinaga, C., Spence, C., Archel, P., Husillos, J., ... Journal, A. (2009). Social disclosure, legitimacy theory and the role of the state. Accounting, Auditing \& Accountability Journal, 22(8), 1284-1307.

Aribi, Z. A., Gao, S., and Gao, S. (2011). between Islamic and conventional financial institutions Corporate social responsibility disclosure. http://doi.org/10.1108/19852511011088352.

Article, E., Akhtaruddin, M., dan Haron, H. (2010). Board ownership , audit committees ' effectiveness , and. http://doi.org/10.1108/13217341011089649.

Baldo, M. Del. (2009). Corporate social responsibility and corporate governance in Italian SMEs: the experience of some spirited businesses. http://doi.org/10.1007/s10997-009-9127-4.

Beckman, T., Khare, A., Matear, M., Beckman, T., Khare, A., and Matear, M. (2016). Does the theory of stakeholder identity and salience lead to corporate social responsibility? The case of environmental justice. http://doi.org/10.1108/SRJ-062015-0072. 
Beurden, P. Van. (2008). The Worth of Values - A Literature Review on the Relation Between Corporate Social and Financial Performance, 407-424. http://doi.org/10.1007/s10551-008-9894-x.

Bhagat, S., and Bolton, B. (2008). Corporate governance and firm performance. Journal of Corporate Finance, 14, 257-273.

Celine, G. (2011). Exploring the Impact of Legal Systems and Financial Structure on Corporate Responsibility. Journal of Business Ethics, 95, 195-222. http://doi.org/10.1007/s10551-011-0854-5.

Chen, J. C., Patten, D. M., and Roberts, R. W. (2008). Corporate Charitable Contributions : A Corporate Social Performance or Legitimacy Strategy?, 131144. http://doi.org/10.1007/s10551-007-9567-1.

Cheng, E. C. M., and Courtenay, S. M. (2006). Board composition, regulatory regime and voluntary disclosure, 41, 262-289. http://doi.org/10.1016/j.intacc.2006.07.001.

Corporate social disclosures in the context of national cultures and stakeholder theory. (2010), 2008. http://doi.org/10.1108/09513571011080162.

Corporate Social Responsibility A Theory of the Firm Perspective 2001.pdf. (n.d.).

Esa, E., Anum, N., dan Ghazali, M. (2012). Corporate social responsibility and corporate governance in Malaysian government-linked companies, 12(3), 292-305. http://doi.org/10.1108/14720701211234564.

Ieng, C., Bikram, C., Alistair, C., Ieng, C., Bikram, C., Alistair, C., ... Wahyuni, D. (2013). The current status of greenhouse gas reporting by Chinese companies A test of legitimacy theory. Managerial Auditing Journal, 28(2), 114-139.

Jamali, D. (2008). A Stakeholder Approach to Corporate Social Responsibility: A Fresh Perspective into Theory and Practice, 213-231. http://doi.org/10.1007/s10551-0079572-4.

Klapper, L. F., and Love, I. (2004). Corporate governance , investor protection , and performance in emerging markets, 10, 703-728. http://doi.org/10.1016/S09291199(03)00046-4.

Kriyantono, R. (2015). Public relations and corporate social responsibility in mandatory approach era in Indonesia, 211(September), 320-327. http://doi.org/10.1016/j.sbspro.2015.11.041.

Lanis, R., and Richardson, G. (2013). Corporate social responsibility and tax aggressiveness : a test of legitimacy theory, 26(1), 75-100. http://doi.org/10.1108/09513571311285621.

Luke, B., Barraket, J., Eversole, R., Mcloughlin, J., Kaminski, J., Sodagar, B.,. Eversole, R. (2013). Measurement as legitimacy versus legitimacy of measures Performance evaluation of social enterprise. http://doi.org/10.1108/QRAM-08-2012-0034.

Luoma-aho, V., Paloviita, A., and Luoma-aho, V. (2010). communications Actornetworking stakeholder theory for today's corporate communications. http://doi.org/10.1108/13563281011016831.

Maharaj, R. (2008). Critiquing and contrasting “" moral "” stakeholder theory and “" strategic ", stakeholder: implications for the board of directors. http://doi.org/10.1108/14720700810863751.

Mohamed, C., Sylvain, D., and Jacques, R. (2014). France' s new economic regulations : insights from institutional legitimacy theory. http://doi.org/10.1108/AAAJ-072013-1415. 
Money, K., Hillenbrand, C., Hunter, I., Money, A. G., Money, K., \& Hillenbrand, C. (2012). Modelling bi-directional research : a fresh approach to stakeholder theory, 4-25. http://doi.org/10.1108/17554251211200428.

Mooij, M. De, and Hofstede, G. (2007). advertising strategy and research The Hofstede model, 29(1), 85-110. http://doi.org/10.2501/S026504870920104X.

Mostovicz, I., Kakabadse, N., \& Kakabadse, A. (2009). CSR : the role of leadership in driving ethical outcomes, 9(4), 448-460. http://doi.org/10.1108/14720700910984990.

Mostovicz, I., Kakabadse, N., Kakabadse, A., Mostovicz, I., Kakabadse, N., and Kakabadse, A. (2012). CSR : the role of leadership in driving ethical outcomes. http://doi.org/10.1108/14720700910984990.

Myburgh, J. E. (2001). Emerald Article: The informativeness of voluntary disclosure in the annual reports of listed industrial companies in South Africa The informativeness of voluntary disclosure in the annual reports of listed industrial companies in South Africa.

Nelson, J. (2005). Corporate governance practices , CEO characteristics and firm performance, 11, 197-228. http://doi.org/10.1016/j.jcorpfin.2003.07.001.

Pierre, J. K., and Florence, V. (2016). Journal of Product \& Brand Management.

Ramli, N., Abdul, N., dan Annuar, S. (2015). Environmental Corporate Social Responsibility ( ECSR ): Exploring its. Procedia Economics and Finance, 31(15), 705-713. http://doi.org/10.1016/S2212-5671(15)01159-4.

Ramli, N., Abdul, N., Irwani, N., Rahman, A., and Khalid, S. A. (2014). Environmental Corporate Social Responsibility ( ECSR ) as a Strategic Marketing Initiatives. Procedia - Social and Behavioral Sciences, 130, 499-508. http://doi.org/10.1016/j.sbspro.2014.04.058.

Reddy, K., Locke, S., and Scrimgeour, F. (2010). The efficacy of principle-based corporate governance practices and firm financial performance An empirical investigation. http://doi.org/10.1108/17439131011056224.

Reverte, C. (2009). Determinants of Corporate Social Responsibility Disclosure Ratings by Spanish Listed Firms Carmelo Reverte, 351-366. http://doi.org/10.1007/s10551-008-9968-9.

Reynolds, M., and Yuthas, K. (2008). Moral Discourse and Corporate Social Responsibility Reporting, 47-64. http://doi.org/10.1007/s10551-006-9316-x.

Rocca, M. La. (2007). The influence of corporate governance on the relation between $\begin{array}{llll}\text { capital structure } \text { and } & \text { 312-325. }\end{array}$ http://doi.org/10.1108/14720700710756580.

Strauss, A. C., and Toit, A. S. A. (2010). Competitive intelligence skills needed to enhance South Africa , s competitiveness. http://doi.org/10.1108/00012531011046925.

Sun, N., Salama, A., Hussainey, K., and Habbash, M. (2010). and earnings management Corporate environmental disclosure, corporate governance and earnings management. http://doi.org/10.1108/02686901011061351.

Tian, G. Y., and Twite, G. (2011). Corporate governance, external market discipline and fi rm productivity, 17, 403-417. http://doi.org/10.1016/j.jcorp. 